\title{
Protective effect of Ocimum sanctum plant extract against DNA damage induced by malathion in cultured human peripheral blood lymphocytes
}

\author{
Neeraj Kumar ${ }^{1}$, Anita Yadav ${ }^{1 *}$, Neeraj Aggarwal ${ }^{2}$ and Ranjan Gupta ${ }^{3}$ \\ ${ }^{1}$ Department of Biotechnology, Kurukshetra University Kurukshetra-1136119 (Haryana), India \\ ${ }^{2}$ Department of Microbiology, Kurukshetra University Kurukshetra-1136119 (Haryana), India \\ ${ }^{3}$ Department of Biochemistry, Kurukshetra University Kurukshetra-1136119 (Haryana), India \\ *Corresponding author
}

\begin{abstract}
A B S T R A C T
Keywords

Malathion,

Comet assay, Tail moment, Ocimum sanctum extract, Human peripheral blood lymphocytes.

Article Info

Accepted:

20 April 2016

Available Online:

10 May 2016

Pesticides are ubiquitous contaminants of our environment and are extensively used all over the world. Malathion is an organophosphate pesticide used to fight against insects in the crop fields. Besides providing protection against insects it also has harmful effects on humans. Its toxicity has been associated with the inhibition of acetyl cholinesterase activity, leading to the interference with the transmission of nerve impulse, accumulation of acetylcholine at synaptic junctions, and subsequent induction of adverse health effects. Keeping in mind the adverse effects of malathion, we therefore studied the protective effect of Ocimum sanctum extract against the malathion induced DNA damage using comet assay as a biomarker of genotoxicity. To observe the protective effect of Ocimum sanctum extract, heparinised fresh blood from healthy individuals was treated with $30 \mu \mathrm{g} / \mathrm{ml}$ of malathion in presence of ocimum extract. Ocimum extract at the concentration of $40 \mu \mathrm{g} / \mathrm{ml}$ and $70 \mu \mathrm{g} / \mathrm{ml}$ had significantly reduced $(\mathrm{p}<0.05)$ the tail moment $(\mathrm{TM})$ as compared to malathion exposed sample. Hence, our findings suggest that Ocimum sanctum extract has protective effect against DNA damage induced by malathion in cultured human peripheral blood lymphocytes.
\end{abstract}

\section{Introduction}

The use of pesticide was first open up to control and abolishes undesirable insects, pests and associated diseases. However with the increased use, these compounds have come out with harmful effects on environment and public health (Bhanti et al., 2007). Organophosphate pesticides are known to produce oxidative stress by inhibiting antioxidant enzymes as well as by inducing generation of reactive oxygen species (ROS) (Lukaszewicz-
Hussain et al., 2010). ROS induce several types of lesions in DNA including single and double strand breaks, which are easily detected by comet assay (Fracasso et al., 2009). The comet assay can be used not only for measuring strand breaks but also DNA nicks associated with repair activities occurring through base excision repair (BER) and nucleotide excision repair (NER) (Slupphaug et al., 2003). 
Among the organophosphate pesticides, Malathion (MLT) is a nonsystemic, widespectrum pesticide because of its relatively low toxicity to mammals and high selectivity towards insects compared to other organophosphorus insecticides. MLT is used in agriculture, commercial extermination, fumigation, veterinary practices, domestic, and public health purposes (Brocardo et al., 2007). MLT increases the level of acetylcholine in pests by phoshorylation of the serine residues in the active centre of acetyl cholinesterase. (Blasiak et al., 1999). Metabolism of malathion produces Malaoxon (a reactive oxygen species) that lead to the onset of oxidative stress (Fortunato et al., 2006).

As plants being a source of attention because of natural constituents derived from any part of plant like bark, leaves, flowers, roots, fruits, seeds etc. are potent biochemists and have been components of phytomedicine. One of such plant having different medicinal property comes under genus ocimum with different species like Ocimum sanctum L (Tulsi), O. gratissimum (Ram Tulsi), O. canum (Dulal Tulsi), $O$. bascilicum (Ban Tulsi), $O$. kilimandschricum, $O$. americanum, $O$. camphora and O. micranthum which grow in different parts of the world like tropical Asia, parts of north and eastern Africa, parts of China, Hainan Island, and Taiwan (Gupta et al., 2002).

Flavonoids isolated from $\mathrm{O}$. sanctum scavenged the free radicals in vitro and showed antiperoxidant activity in vivo at a very low concentration. (Uma et al., 2000). Ocimum sanctum L. represent different therapeutic properties like antigenotoxicity, antioxidant, antimicrobial, immunomodulatory, anticancer and antiinflammatory properties in animal models under in vitro testing (Parkash, 2000; Geeta 2001; Yanpallewar, 2004; Mukherjee, 2005;
Hannan, 2006). Fresh leaves and stem of Tulsi contains phenolic compounds like cirsilineol, circimaritin, isothymusin, apigenin and rosmeric acid and appreciable quantities of eugenol. Most of these chemical possess beneficial health effects and exhibit diverse pharmacological effects. (Baliga et al., 2013). Taking into account the ill effects of MLT, we investigated the protective effect of extract of Ocimum sanctum against DNA damage induced by MLT by employing comet assay to measure level of DNA damage.

\section{Materials and Methods}

\section{Ocimum Extract Preparation}

Ocimum extract was prepared from commercially available ocimum tablets. The stock solution $(1 \mathrm{mg} / \mathrm{ml})$ was prepared in DMSO, sterile filtered $(0.22 \mu \mathrm{m})$ and stored at $-20^{\circ} \mathrm{C}$ until use.

\section{Sample Collection}

$5 \mathrm{ml}$ venous blood was taken from healthy individuals in vacutainer tubes containing sodium heparin as an anticoagulant for lymphocyte culture set up. Subjects having exposure to diagnostic X-rays, drug intake and vaccination for last six months prior to blood sampling have not been included in study. A consent form and questionnaire was also got filled by the donors for their health status history and consent. All the individuals participated in the study were male of age group 18 to 30 years and were bonafide resident of Haryana state, North India (Aryan race). The protocol was duly approved by human ethical committee of Kurukshetra University.

\section{Human Lymphocyte Culture}

Short term peripheral blood lymphocyte (PBL) cultures were set up using earlier 
studied technique of Moorhead et al., 1960 with minor modifications. Culture was set up in duplicate by adding $(0.4 \mathrm{ml})$ whole heparinized blood into $5 \mathrm{ml}$ of RPMI 1640 culture medium (Himedia) containing Lglutamine (1\%), fetal calf serum (20\%) (Himedia), penicillin (100 UI/ml) and streptomycin $\quad(100 \mu \mathrm{g} / \mathrm{ml}) \quad$ solution (Himedia), and phytohaemagglutinin (2\%) (Bangalore Genei). Malathion (Sigma) was added at the beginning of culture at the concentration of $30 \mu \mathrm{g} / \mathrm{ml}$. To check protective effect of ocimum extract against malathion, cultures were set up separately having various combinations of malathion and ocimum extract. In one set up, heparinised fresh blood was treated with 30 $\mu \mathrm{g} / \mathrm{ml}$ of malathion along with $40 \mu \mathrm{g} / \mathrm{ml}$ concentrations of ocimum extract while in other $70 \mu \mathrm{g} / \mathrm{ml}$ concentrations of ocimum extract was added against $30 \mu \mathrm{g} / \mathrm{ml}$ concentration of malathion. Blood was also treated with ocimum extract alone to check its genotoxic effects, if any. Blood without malathion and ocimum extract acted as control while blood having Dimethylsulphoxide (DMSO) was taken as negative control. The cultures were then incubated for 24 hours at $37^{\circ} \mathrm{C}$ and $5 \%$ $\mathrm{CO} 2$. The cells were harvested by centrifugation and washed in phosphate buffer saline (PBS). The lymphocytes were then resuspended in $1 \mathrm{ml}$ Phosphate Buffer Saline (PBS).

\section{Comet Assay}

Alkaline comet assay was performed according to the method of Singh et al., (1988) and Tice et al., (2000) with minor modifications. Briefly, lymphocytes (10-20 $\mu 1)$ were mixed with $80 \mu \mathrm{l}$ of warm $0.5 \%$ low melting agarose (Sigma) and this mixture was layered as second additional layer over first layer of $1 \%$ normal melting agarose (Sigma) and gelled at $4{ }^{\circ} \mathrm{C}$ for 15 minutes. A third additional layer of $150 \mu \mathrm{l}$ of $0.5 \%$ low melting agarose was added on top and gelled again at $4{ }^{\circ} \mathrm{C}$ for 15 minutes. The slides were treated for 2 hours at $4{ }^{\circ} \mathrm{C}$ in freshly prepared, chilled lysis buffer solution (25 mM sodium chloride, $100 \mathrm{mM}$ sodium EDTA, $10 \mathrm{mM}$ tris, $1 \%$ triton $\mathrm{X}-100,10 \%$ DMSO added before use and $\mathrm{pH}$ adjusted to 10) followed by incubation in alkaline electrophoresis buffer $(10 \mathrm{~N}$ sodium chloride, $200 \mathrm{mM}$ EDTA, $\mathrm{pH}$ adjusted to 13) for 20 minutes and electrophoresis $(25 \mathrm{~V}$ and $300 \mathrm{~mA}$ ) for 30 minutes in the same buffer.. The slides were then neutralized with tris buffer $(0.4 \mathrm{M}$ tris, $\mathrm{pH}$ adjusted to $7.5)$, rinsed with distilled water and stained with ethidium bromide $(20 \mu \mathrm{g} / \mathrm{ml})$ for 5 minutes under dark condition.

\section{Comet Scoring}

A total of 50 individual cells from each of the duplicate slides per subject were examined randomly under Olympus fluorescence microscope with $535 \mathrm{~nm}$ absorbance green emission filter. Undamaged cells have an intact nucleus without a tail and damaged cells have the appearance of a comet. The extent of DNA damage was measured quantitatively as tail moment (TM) value using Lucia comet assay software (Version 7.12). The TM is defined as the percentage of DNA in the tail multiplied by the length between the centre of the head and tail (Olive et al., 1990).

\section{Statistical Analysis}

All treatments were performed in duplicates and results were expressed as means \pm S.D. The student $t$ test was used for calculating the statistical significance using SPSS 16.0.

\section{Results and Discussion}

We studied the protective effects of ocimum extract against the genotoxicity induced by malathion in cultured PBL. DNA damage 
was examined in terms of TM value using comet assay. Malathion was observed alone for their mutagenicity by using various concentrations. PBL treated with malathion manifested a higher amount of DNA damage expressed in terms of TM. As the concentration of malathion increased from 10 to $30 \mu \mathrm{g} / \mathrm{ml}$, TM was also increased and reached maximum at $30 \mu \mathrm{g} / \mathrm{ml}$ (Data communicated). Out of these concentrations, $30 \mu \mathrm{g} / \mathrm{ml}$ concentrations of malathion had shown maximum significant DNA damage to PBL and hence this concentration was finally chosen for analyzing protective effect of ocimum extract. Ocimum extract had shown protective effect in dose dependent manner against malathion as there was significant reduction $(\mathrm{P}<0.05)$ in $\mathrm{TM}$ as compared to the PBL treated with malathion only (Table 1 and figure 1). Ocimum extract was also analyzed for any genotoxic effect in absence of malathion and there was no significant increase in TM was found with the doses of ocimum extract used i.e. 40 and $70 \mu \mathrm{g} / \mathrm{ml}$, as compared to untreated PBL
(Table 2).

Hence, it was observed that Ocimum sanctum extract had protected the cultured human PBL against the deleterious effect of malathion.

In the present study, we evaluated the genoprotective effect of Ocimum against malathion induced genotoxicity in human PBL using comet assay. We observed that malathion induces a significant $(\mathrm{P}<0.05)$ increase in tail moment as compare to untreated PBL. Similar to our findings, several reports are available in literature supporting the genotoxicity of malathion. Błasiak et al., (1999) found that malathion and its isomer isomalathion were genotoxic to cultured human peripheral blood lymphocytes (PBL). Malathion was also found to be genotoxic to freshwater teleost fish Channa punctatus (Bloch) using micronucleus $(\mathrm{MN})$ and comet assay as a biomarker of genotoxicity (Kumar et al., 2010).

Table.1 Protective Effect of Ocimum Extract Against Malathion Induced DNA Damage

\begin{tabular}{|c|c|c|}
\hline Treatments & Concentrations USED $(\boldsymbol{\mu g} / \mathbf{m l})$ & Tail Moment $($ Mean \pm SD) \\
\hline Control & Untreated & $1.98 \pm 0.17$ \\
\hline M & 30 & $10.53 \pm 0.48^{\mathrm{a}}$ \\
\hline M+ O.E. & $30+40$ & $6.37 \pm 0.32^{\mathrm{b}}$ \\
\hline M+ O.E. & $30+70$ & $3.28 \pm 0.21^{\mathrm{c}}$ \\
\hline DMSO (negative control) & 20 & $1.64 \pm 0.14^{\mathrm{d}}$ \\
\hline
\end{tabular}

*M: Malathion, *O.E.: Ocimum Extract, *DMSO: Dimethylsulphoxide; ${ }^{\mathrm{a}} \mathrm{P}<0.05$ significant as compare to untreated; ${ }^{b} \mathrm{P}<0.05$ significant as compare to malathion treatment; ${ }^{\mathrm{c}} \mathrm{P}>0.05$ Non-significant as compare to untreated

Table.2 Non-Mutagenic Effect of Ocimum Extract

\begin{tabular}{|c|c|c|}
\hline Treatments & $\begin{array}{c}\text { Concentrations Used } \\
(\boldsymbol{\mu g} / \mathbf{m l})\end{array}$ & $\begin{array}{c}\text { Tail Moment } \\
(\text { Mean } \pm \text { SD) }\end{array}$ \\
\hline Control & Untreated & $1.98 \pm 0.17$ \\
\hline O.E. & 40 & $2.05^{\mathrm{c}} \pm 0.23^{\mathrm{d}}$ \\
\hline O.E. & 70 & $2.17^{\mathrm{c}} \pm 0.19^{\mathrm{d}}$ \\
\hline
\end{tabular}

*O.E.: Ocimum Extract; ${ }^{\mathrm{d}} \mathrm{P}>0.05$ Non-significant as compare to untreated 
Fig.1 Reduction in TM by Ocimum Extract against Malathion Treated Cultured Human PBL

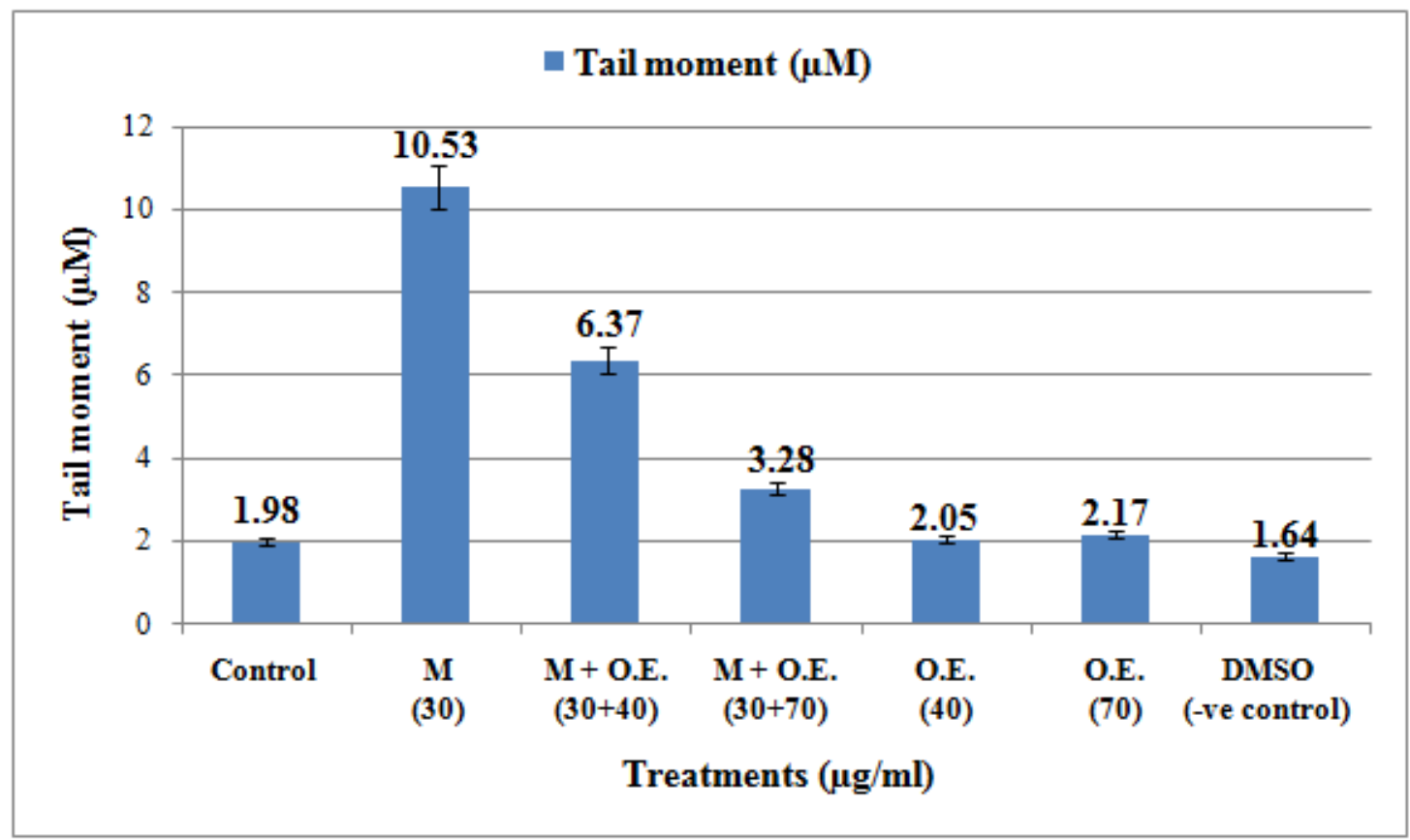

*M: Malathion, *O.E.: Ocimum Extract, *DMSO: Dimethylsulphoxide

Several cell culture studies also reported the genotoxicity of malathion using comet assay in terms of increased TM value. Moore et al., (2009) reported that malathion is genotoxic to Human liver carcinoma (HepG2) cells. They observed the significant increase in DNA damage at the $24 \mathrm{mM}$ malathion exposure using comet assay. The role of oxidative stress in malathion-induced cytotoxicity and genotoxicity was also examined by Moore et al., (2009). To achieve this goal, MTT, lipid peroxidation, and single cell gel electrophoresis (Comet) assays were performed, respectively, to evaluate the levels of cell viability, malondialdehyde (MDA) production, and DNA damage in human liver carcinoma (HepG2) cells. HepG2 cells were treated with malathion $(6,12,18$, and $24 \mathrm{mM})$ and comet assay was performed. Study results indicated that malathion is mitogenic at lower levels of exposure, and cytotoxic at higher levels of exposure. Upon $48 \mathrm{~h}$ of exposure with $24 \mathrm{mM}$ malathion, the comet assay showed a significant increase in percentage of DNA damage and comet tail length. The percentages of DNA cleavage were $7.93 \% \pm 4.51 \%, 9.71 \% \pm 5.48 \%$, $13.16 \% \pm 7.87 \%, 14.65 \% \pm 5.29 \%$, and $27.3 \% \pm 11.16 \%$ for $0,6,12,18$, and $24 \mathrm{mM}$ of malathion, respectively. These findings suggest that oxidative stress plays an important role in malathion-induced cytotoxic and genotoxic damage in HepG2 cells.

Genotoxicity of malathion was also demonstrated by Dalia and Abd El-Monem, (2011) in male albino rats. The alkaline comet assay showed significantly increased tail moment in liver cells of animals treated with malathion alone compared to control group. Hence the results indicated that malathion treatment induces cytotoxic and genotoxic effects in bone marrow cells, and liver cells of albino rats. Similarly, Xian et 
al., (2012) also evaluated the cytotoxic and genotoxic effects of five OPs or metabolites, Acephate (ACE), Methamidophos (MET), Chloramidophos (CHL), Malathion (MAT) and Malaoxon (MAO), and clarified the role of oxidative stress, using Pheochromocytoma (PC12) cells of rat adrenal medulla. DNA damage studies were carried out using a comet assay. DNA damage represented by DNA single-strand breaks was reflected by an increase in tail moments. Their results demonstrated that MET, MAT and MAO caused significant inhibition of cell viability and increased DNA damage in PC12 cells at $40 \mathrm{mg} / \mathrm{l}$. Considering tail length, at a concentration of $20 \mathrm{mg} / \mathrm{l}$, only MAO induced significant effect on DNA damage, when the concentration was increased to $40 \mathrm{mg} / \mathrm{l}$ the other OPs, with the exception of CHL, all induced significant DNA damage.

The results of the present study support the protective role of ocimum extract against malathion which is supported by many investigations. Batra and Sastri (2015) studied the anti-toxic effects of Ocimum sanctum derivatives (ursolic acid-1 and ursolic acid-2) on hydrogen peroxide induced toxicity in human lymphocytes using comet assay as a biomarker to assess DNA damage. They observed that $60 \mu \mathrm{M}$ of ursolic acid-2 has significantly reduced the DNA damage caused by hydrogen peroxide as measured in terms of tail moment. Similarly, Vijaya et al., (2014) studied the antigenotoxic effect of green-synthesised silver nanoparticles from Ocimum sanctum leaf extract against cyclophosphamide (CP) induced genotoxicity in human PBL using chromosomal aberration assay (CAA). The three doses $(50,100$ and $200 \mu \mathrm{l} / \mathrm{ml})$ of Ocimum sanctum leaf extract had significantly $(\mathrm{P}<0.005)$ reduced the chromosomal damages induced by $\mathrm{CP}$. Hence they found the bio-synthesised silver nanoparticless of Ocimum sanctum leaf extract as a powerful genoprotectant.

Similar to our findings, Khanna et al., (2011) also observed the protective effect of Ocimum sanctum against chlorpyrifos induced genotoxicity under in vitro conditions. They exposed the human lymphocyte cultures to $75 \mu \mathrm{g} / \mathrm{ml}$ chlorpyrifos with and without ocimum extract (OE). Chromosomal aberrations (CA) assay was used for the assessment of DNA damage. A significant $(\mathrm{P}<0.05)$ increase in CA was observed in PBL treated with $75 \mu \mathrm{g} / \mathrm{ml}$ chlorpyrifos as compared to controls, while $\mathrm{OE}$ at $12 \mu \mathrm{g} / \mathrm{ml}$ had significantly $(\mathrm{P}<0.05)$ decreased the $\mathrm{CA}$. Another study performed by Dutta et al., (2007) also supports our findings. They observed the modulatory effect of distillate of Ocimum sanctum leaf extract (DTLE) on Human PBL against genetic damage induced by mitomycin $\mathrm{C}$ (MMC), Benzopyrene and hexavalent chromium $(\mathrm{Cr}+6)$ using chromosomal aberration $(\mathrm{CA})$ and micronucleus assay $(\mathrm{MN})$ as biomarkers of DNA damage. Their findings suggests that MMC, $\mathrm{Cr}+6$ and Benzopyrene had induced the $\mathrm{CA}$ and $\mathrm{MN}$ formation while DTLE at concentrations of 50, 100, and 200 $\mu 1 / \mathrm{ml}$ had significantly $(\mathrm{P}<0.001)$ protected the cells against $\mathrm{CA}$ and $\mathrm{MN}$ formation.

On the basis of above findings, we can suggest that malathion is cytotoxic and genotoxic to cultured human PBL under in vitro conditions and use of Ocimum sanctum extract can help us to fight against its deleterious health effects.

\section{Acknowledgement}

This work was proposed and guided by Dr. Anita Yadav. The work was carried out in Animal Biotechnology Laboratory, Department of Biotechnology, Kurukshetra 
University, Kurukshetra (Haryana), India. We are thankful to all blood donors for their useful contribution in our research.

\section{References}

Baliga, M.S., Jimmy, R., Thilakchand, K.R., Sunitha, V., Bhat, N.R., Saldanha, E., Rao, S., Rao, P., Arora, R., Palatty, P.L., 2013. Ocimum sanctum L (Holy Basil or Tulsi) and its phytochemicals in the prevention and treatment of cancer. Nutr. Cancer. 65(1): 26-35.

Batra, A., Sastri, G., 2015. Extraction of ursolic acid from Ocimum sanctum and synthesis of its derivatives: Derivatization of C-3 positions and C28 position enhances protective effect against hydrogen peroxide induced oxidative stress in human lymphocytes. J. Chem. Pharma. Res. 7(4): 679-691.

Bhanti, M., Taneja, A., 2007. Contamination of vegetables of different seasons with organophosphorous pesticides and related health risk assessment in northern India. Chemo. 69(1): 63-8.

Blasiak, J., Jaloszynski, P., Trzeciak, A., Szyfter, K., 1999. In vitro studies on the genotoxicity of the organophosphorus insecticide malathion and its two analogues. Mutat Res Genet Toxicol Environ Mutagen. 445(2): 275-283.

Brocardo, P.S., Assini, F., Franco, J.L., Pandolfo, P., Muller, Y.M., Takahashi, R.N., Dafre, A.L., Rodrigues, A.L.S., 2007. Zinc Attenuates MalathionInduced Depressant-like Behavior and Confers Neuroprotection in the Rat Brain. Toxicol. Sci. 97(1): 140-148.

Dalia, D., El-Monem, A., 2011. The Ameliorative Effect of Royal Jelly against Malathion Genotoxicity in Bone Marrow and Liver of Rat. J. Am. Sci. 7(12): 1251-1256.

Devi, P.U., Ganasoundari, A., Vrinda, B., Srinivasan, K.K., Unnikrishnan, M.K., 2000. Radiation Protection by the Ocimum Flavonoids Orientin and
Vicenin: Mechanisms of Action. Rad. res. 154(4): 455-460.

Dutta, D., Devi, S.S., Krishnamurthi, K., Kumar, K., Vyas, P., Muthal, P.L., Naoghare, P., Chakrabarti, T., 2007. Modulatory Effect of Distillate of Ocimum msanctum Leaf Extract (Tulsi) on Human Lymphocytes Against Genotoxicants. Biomed. Environ. Sci. 20: 226-234.

Fortunato, J.J., Feier, G., Vitali, A.M., Petronilho, F.C., Dal-Pizzol, F., Quevedo, J., 2006. Malathion-induced oxidative stress in rat brain regions. Neurochem. Res. 31(5): 671-678.

Fracasso, M.E., Doria, D., Carrieri, M., Bartolucci, G.B., Quintavalle, S., De Rosa, E., 2009. DNA single and doublestrand breaks by alkaline- and immunocomet assay in lymphocytes of workers exposed to styrene. Toxicol. Lett. 185(1): 9-15.

Geeta, Vasudevan, D.M., Kedlaya, R., Deepa, S., Ballal, M., 2001. Activity of Ocimum sanctum (the traditional Indian medicinal plant) against the enteric pathogens. Ind. J. Med. Sci. 55(8): 434438.

Gupta, S.K., Parkash, J., Srivastava, S., 2002. Validation of traditional claim of tulsi, Ocimum sanctum linn. as a medicinal plant. Ind. J. Exp. Biol. 40: 765-773.

Hannan, J.M., Marenah, L., Ali, L., Rokeya, B., Flatt, P.R., Abdel-Wahab, Y.H., 2006. Ocimum sanctum leaf extracts stimulate insulin secretion from perfused pancreas, isolated islets and clonal pancreatic beta-cells. J. Endocrinol. 189(1): 127-136.

Hussain, A.L., 2010. Role of oxidative stress in organophosphate insecticide toxicityPest. Biochem. Physiol. 98(2): 145-150.

Khanna, A., Shukla, P., Tabassum., 2011. Role of Ocimum sanctum as a Genoprotective Agent on Chlorpyrifos Induced Genotoxicity. Toxicol. Int. 18(1): 9-13. 
Kumar, R., Nagpure, N.S., Kushwaha, B., Srivastava, S.K., Lakra, W.S., 2010. Investigation of the genotoxicity of malathion to freshwater teleost fish Channa punctatus (Bloch) using the micronucleus test and comet assay. Arch. Environ. Contam. Toxicol. 58(1): 123-130.

Moore, P.D., Yedjou, C.G., Tchounwou, P.B., 2009. Malathion-Induced Oxidative Stress, Cytotoxicity, and Genotoxicity in Human Liver Carcinoma (HepG2) Cells. Environ. Toxicol. 25 (3): 221226.

Moorhead, P.S., Nowell, P.C., Mellman, W.J., Battips, D.M., Hungerford, D.A., 1960. Chromosome preparations of leukocytes cultured from human peripheral blood. Exp. Cell. Res. 20(3): 613-616.

Mukherjee, R., Dash, P.K., Ram, G.C., 2005. Immunotherapeutic potential of Ocimum sanctum (L) in bovine subclinical mastitis. Res. Vet. Sci. 79(1): 37-43.

Olive, P.L., Banath, J.P., Durand, R.E., 1990. Heterogeneity in radiation induced DNA damage and repair in tumor and normal cells using the comet assay. Rad. Res. 122: 86-94.

Prakash, J., Gupta, S.K., 2000. Chemopreventive activity of Ocimum sanctum seed oil. J. Ethnopharmacol. 72(1-2): 29-34.

Singh, N.P., McCoy, M.T., Tice, R.R., Schneider, E.L., 1988. A simple technique for quantitation of low levels of DNA damage in individual cells. Exp. Cell. Res. 175: 184-191.
Slupphaug, G., Kavli, B., Krokan, H.E., 2003. The interacting pathways for prevention and repair of oxidative DNA damage. Mut. Res. 531(1-2): 231-251.

Tice, R.R., Agurell, E., Anderson, D., Burlinson, B., Hartmann, A., Kobayashi, H., Miyamae, Y., Rojas, E., Ryu, J.C., Sasaki, Y.F., 2000. Single Cell Gel/Comet Assay: Guidelines for In Vitro and In Vivo Genetic Toxicology Testing. Environ. Mol. Mutagen. 35: 206-221.

Vijaya, P.P., Rekha, B., Mathew, A.T., Syed, A. M., Yogananth, N., Anuradha, V., Kalitha, Parveen, P., 2014. Antigenotoxic effect of greensynthesised silver nanoparticles from Ocimum sanctum leaf extract against cyclophosphamide induced genotoxicity in human lymphocytes - invitro. App. Nanosci. 4(4): 415-420.

Xian, T.L., Yun, M., Cui, W., Xiao, F.Z., Da, Q.J., Chang, J.H., 2001. Cytotoxicity and DNA damage of five organophosphorus pesticides mediated by oxidative stress in PC12 cells and protection by vitamin E. . J. Environ. Sci Health Part B. 4: 445-454.

Yanpallewar, S.U., Rai, S., Kuma,r M., Acharya, S.B., 2004. Evaluation of antioxidant and neuroprotective effect of Ocimum sanctum on transient cerebral ischemia and long-term cerebral hypoperfusion. Pharmacol. Biochem. Behav. 79 (1): 155-164.

\section{How to cite this article:}

Neeraj Kumar, Anita Yadav, Neeraj Aggarwal and Ranjan Gupta. 2016. Protective effect of Ocimum sanctum plant extract against DNA damage induced by malathion in cultured human peripheral blood lymphocytes. Int.J.Curr.Microbiol.App.Sci.5(5): 840-847.

doi: http://dx.doi.org/10.20546/ijcmas.2016.505.086 